Konstantina

Chalmoukou, MD*

Harry Alexopoulos, DPhil*

Sofia Akrivou, BSc

Panos Stathopoulos, MD, $\mathrm{PhD}$

Markus Reindl, PhD

Marinos C. Dalakas, MD

Neurol Neuroimmunol

Neuroinflamm

2015;2:e131; doi: 10.1212

NXI.0000000000000131

Supplemental data at Neurology.org/nn

\section{ANTI-MOG ANTIBODIES ARE FREQUENTLY ASSOCIATED WITH STEROID-SENSITIVE RECURRENT OPTIC NEURITIS \\ OPEN}

Optic neuritis $(\mathrm{ON})$ is an inflammatory disease of the optic nerve characterized by pain and visual loss and often associated with multiple sclerosis (MS) or neuromyelitis optica spectrum disorders (NMOSD). Recent evidence suggests that certain forms of $\mathrm{ON}$ are associated with anti-myelin oligodendrocyte glycoprotein (MOG) antibodies. ${ }^{1-4}$

A distinct clinical subset of $\mathrm{ON}$ is characterized by multiple episodes that involve one or both optic nerves, occur within months or weeks, and do not involve any other associated clinical or radiologic findings. This entity, defined as either recurrent optic neuritis (rON) or chronic relapsing inflammatory optic neuritis (CRION), ${ }^{5}$ is typically corticosteroid-responsive and corticosteroid-dependent, often requiring immunosuppressive therapy for corticosteroid-sparing effect.

Our aim was to determine whether aquaporin-4 (AQP4)-negative patients with ON harbor antibodies to MOG and whether anti-MOG antibodies are clinically relevant.

Methods. We examined sera from 111 patients initially referred to our diagnostic service for AQP4 testing. These patients had at least one episode of unilateral or bilateral $\mathrm{ON}$, as reported by their referring physicians. All 111 patients were APQ4-negative. Twelve patients with primary progressive MS and 30 patients with relapsing-remitting MS (RRMS) were used as disease controls. The Ethics Committee of the University of Athens granted ethical approval.

Anti-MOG screening was performed using a cellbased-assay (CBA). Patient sera (1:60 dilution) were applied on live human embryonic kidney 293T cells and transiently transfected with full-length $\mathrm{MOG}$ enhanced green fluorescent protein followed by a goat anti-human secondary antibody (Alexa Fluor 568). Positive samples were retested and titrated in a blinded fashion by M.R.

To investigate optic nerve specificity, anti-MOGpositive sera were applied onto $10 \mu \mathrm{m}$ nonfixed or $2 \%$ paraformaldehyde-fixed sections of fresh frozen human optic nerves (Netherlands Brain Bank,
Amsterdam). A commercial monoclonal anti-MOG antibody was used as a positive control (Millipore, Billerica, MA; clone 8-18C5).

Results. Anti-MOG antibodies were detected by CBA in 8/111 AQP4-seronegative patients and in 0/42 MS disease controls (figure 1, B-D). All 8 MOG-positive patients had at least one episode of $\mathrm{ON}$, and 5 of them fulfilled the criteria for rON/ CRION (defined as $\geq 3$ episodes of $O N$ within a period of a few months to a year). Fifteen of 30 patients with RRMS had at least one episode of $\mathrm{ON}$, and 10 of the 15 had a relapsing ON course.

The 5 patients with rON/CRION (followed by M.C.D. for 2-11 years) had recurrent disease confined to optic nerves, often associated with or preceded by pain. Brain/orbital MRI or CSF analyses were normal except for optic nerve enhancement in 2 patients. Spinal MRI depicted one small subclinical chronic lesion in the cervical spine in one of the patients who never developed any clinical symptoms of myelitis. Antibody titers did not correlate with disease severity or number of relapses (figure 1A). All received IV steroids during the early attacks, but they were subsequently maintained on a low-dose oral regimen. In 2 patients, the attacks occurred very frequently when the oral corticosteroid dose was lowered below 15-20 mg every other day, necessitating the concurrent administration of an immunosuppressant such as mycophenolate mofetil. One patient with multiple episodes over many years who eventually developed optic atrophy in one eye also received rituximab without success; relative stability (only 1 or 2 episodes yearly) was induced by bimonthly plasmapheresis (figure e-1 at Neurology.org/nn).

As human MOG antibodies do not recognize paraffin-fixed denaturated epitopes, ${ }^{6}$ we used freshfrozen, nonfixed, or lightly fixed human optic nerve tissue as substrate. No specific binding of the patients' sera or IgG was observed (figure e-2A).

Discussion. We have characterized and longitudinally followed up 5/8 patients with anti-MOGpositive rON/CRION without spinal cord or brain symptomatology These patients do not fall within the rubric of NMOSD, and our follow-up revealed that relapses were confined to the optic nerves and were highly sensitive to even low doses of oral 
A

\begin{tabular}{|c|c|c|c|c|c|c|c|}
\hline Patient \# & $M / F$ & $\begin{array}{l}\text { Age of first } \\
\text { ON episode }\end{array}$ & $\begin{array}{l}\text { Clinical } \\
\text { features }\end{array}$ & $\begin{array}{l}\text { Episodes } \\
\text { of ON }\end{array}$ & $\begin{array}{c}\text { Brain \& } \\
\text { spinal MRI }\end{array}$ & MOG titers & Treatment \\
\hline 1 & M & 46 & rON, pain & $\begin{array}{l}\geq 3 \text { in a } \\
\text { year }\end{array}$ & Normal & $1: 320$ & Low-dose oral CS \\
\hline 2 & M & 41 & rON, pain & $\begin{array}{l}2-12 \text { in a } \\
\text { year }\end{array}$ & Normal & $1: 320$ & $\begin{array}{l}\text { Low-dose oral CS, } \\
\text { mycophenolate mofetil, } \\
\text { rituximab, PE }\end{array}$ \\
\hline 3 & $\mathrm{~F}$ & 40 & $\begin{array}{l}\text { Bilateral } \\
\text { rON, pain }\end{array}$ & $\begin{array}{l}\geq 3 \text { in a } \\
\text { year }\end{array}$ & Normal & 1:160 & Low-dose oral CS \\
\hline 4 & $\mathrm{~F}$ & 43 & $\begin{array}{c}\text { ON, pain, } \\
\text { nausea }\end{array}$ & No data & Normal & $>1: 640$ & Low-dose oral CS \\
\hline 5 & $\mathrm{~F}$ & 21 & $\begin{array}{l}\text { Bilateral } \\
\text { ON, pain }\end{array}$ & No data & $\begin{array}{l}\text { C3-C4 } \\
\text { lesion }\end{array}$ & $>1: 640$ & Low-dose oral CS, IVIg \\
\hline 6 & $\mathrm{~F}$ & 37 & $\begin{array}{c}\text { Bilateral } \\
\text { rON, pain }\end{array}$ & No data & Normal & 1:160 & Low-dose oral CS \\
\hline 7 & $\mathrm{~F}$ & 20 & rON, pain & $\begin{array}{c}2-7 \text { in a } \\
\text { year }\end{array}$ & Normal & $>1: 640$ & $\begin{array}{l}\text { Low-dose oral CS, } \\
\text { mycophenolate mofetil }\end{array}$ \\
\hline 8 & $\mathrm{~F}$ & 42 & rON, pain & $\begin{array}{l}\geq 3 \text { in a } \\
\text { year }\end{array}$ & Normal & 1:160 & Low-dose oral CS \\
\hline
\end{tabular}
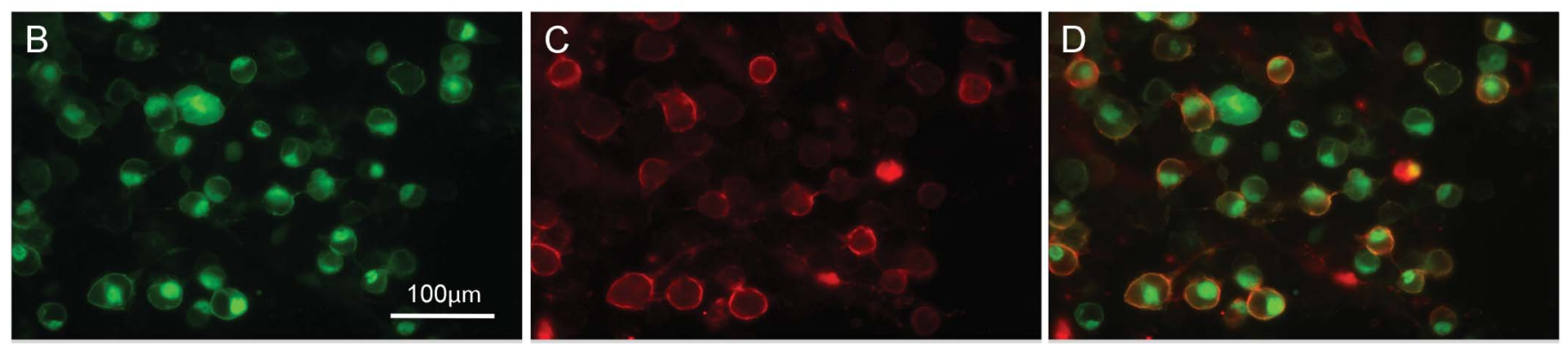

(A) Clinical characteristics of myelin oligodendrocyte glycoprotein (MOG)-positive patients with recurrent optic neuritis (rON). (B-D) Cell-based assay of a representative patient. (B) MOG- enhanced green fluorescent protein (EGFP) transfected human embryonic kidney 293T cells. (C) Immunostaining with serum of a representative patient with rON on live non-permeabilized MOG-EGFP transfected cells. (D) Merged immunofluorescence image that shows colocalization. Scale bar $=100 \mu \mathrm{m}$. CS = corticosteroids; IVIg = IV immunoglobulin; ON = optic neuritis; PE = plasma exchange.

corticosteroids. Our results confirm recent observations $^{3,4}$ that anti-MOG antibodies are frequently associated with recurrent forms of $\mathrm{ON}$.

Anti-MOG antibodies have also been associated with pediatric inflammatory demyelinating diseases, including acute disseminated encephalomyelitis. ${ }^{7} \mathrm{~A}$ comparative epitope mapping of MOG antibodies from different syndromes identified a dominant MOG epitope but failed to elucidate a causative relationship or define distinct clinical phenotypes. ${ }^{6}$ No binding of patients' sera was observed in our optic nerve preparations, in which native epitopes are preserved. Whether the rON-associated anti-MOG antibodies are pathogenic, causing conduction block in the optic nerve, demyelination, or edema, remains unclear.

Our observations suggest that anti-MOG antibodies are frequently associated with the rON/CRION phenotype, which is a highly steroid-responsive disorder. Although the rON series is small, the finding is supported by the observation that all of the RRMS control patients with ON were MOG-seronegative.

* These authors contributed equally to this work.

From the Neuroimmunology Unit (K.C., H.A., S.A., P.S., M.C.D.), Department of Pathophysiology, Faculty of Medicine, National and Kapodistrian University of Athens, Greece; Clinical Department of Neurology (M.R.), Medical University of Innsbruck, Austria; and Department of Neurology (M.C.D.), Thomas Jefferson University, Philadelphia, PA.

Author contributions: Dr. Alexopoulos and Dr. Dalakas: study concept and design. Dr. Chalmoukou, Dr. Alexopoulos, Ms. Akrivou, Dr. Reindl, and Dr. Dalakas: acquisition of data. Dr. Chalmoukou, Dr. Alexopoulos, and Dr. Stathopoulos: data analysis and interpretation. Dr. Alexopoulos, Dr. Reindl, and Dr. Dalakas: drafting and critical revision of the manuscript.

Study funding: No targeted funding reported.

Disclosure: K. Chalmoukou, H. Alexopoulos, and S. Akrivou report no disclosures. P. Stathopoulos received research support from Yale 
and Hellenic Neurological Society. M. Reindl is an academic editor for PLOS ONE; is on the editorial board for Current Medicinal Chemistry and Autoimmune Diseases; and received research support from Austrian Science Fund and Austrian Federal Ministry of Science. M. Reindl and Medical University of Innsbruck receive payments for antibody assays (AQP4 and antineuronal antibodies) and for AQP4 antibody validation experiments organized by Euroimmun. M.C. Dalakas is on the scientific advisory board for Novartis; received travel funding andlor speaker honoraria from Baxter, CSL, Servier, Novartis, Hoffman LaRoche, and MerckSerono; is on the editorial board for Neurology, Acta Myologica, and Acta Neurologica Scandinavica; is a section editor for BMC Neurology; is an associate editor for Therapeutic Advances in Neurology; has consulted for Therapath, Grifols, Novartis, Baxter, Octapharma, Hoffman LaRoche, Servier, and CSL; and received institutional support to Thomas Jefferson University or University of Athens Medical School from Merck-Serono, Genzyme, Novartis, CSL, Biogen, Genesis, TEVA, and Newfactor. Go to Neurology. org/nn for full disclosure forms. The Article Processing Charge was paid by the Institute of Autoimmune, Systemic and Neurological Disorders.

This is an open access article distributed under the terms of the Creative Commons Attribution-NonCommercial-NoDerivatives License 4.0 (CC BY-NC-ND), which permits downloading and sharing the work provided it is properly cited. The work cannot be changed in any way or used commercially.

Received February 24, 2015. Accepted in final form May 21, 2015.

Correspondence to Dr.Dalakas: mdalakas@med.uoa.gr
1. Kitley J, Woodhall M, Waters P, et al. Myelin-oligodendrocyte glycoprotein antibodies in adults with a neuromyelitis optica phenotype. Neurology 2012;79:1273-1277.

2. Rostásy K, Mader S, Hennes EM, et al. Persisting myelin oligodendrocyte glycoprotein antibodies in aquaporin-4 antibody negative pediatric neuromyelitis optica. Mult Scler 2013;19:1052-1059.

3. Ramanathan S, Reddel SW, Henderson A, et al. Antibodies to myelin oligodendrocyte glycoprotein in bilateral and recurrent optic neuritis. Neurol Neuroimmunol Neuroinflamm 2014;1:e40; doi: 10.1212/NXI.0000000000000040.

4. Martinez-Hernandez E, Sepulveda M, Rostásy K, et al. Antibodies to aquaporin 4, myelin-oligodendrocyte glycoprotein, and the glycine receptor $\alpha 1$ subunit in patients with isolated optic neuritis. JAMA Neurol 2015;72:187-193.

5. Kidd D, Burton B, Plant GT, Graham EM. Chronic relapsing inflammatory optic neuropathy (CRION). Brain 2003; 126:276-284.

6. Mayer MC, Breithaupt C, Reindl M, et al. Distinction and temporal stability of conformational epitopes on myelin oligodendrocyte glycoprotein recognized by patients with different inflammatory central nervous system diseases. J Immunol 2013;191:3594-3604.

7. Reindl M, Di Pauli F, Rostásy K, Berger T. The spectrum of MOG autoantibody-associated demyelinating diseases. Nat Rev Neurol 2013;9:455-461. 


\section{Neurology \\ Neuroimmunology \& Neuroinflammation}

\section{Anti-MOG antibodies are frequently associated with steroid-sensitive recurrent optic neuritis}

Konstantina Chalmoukou, Harry Alexopoulos, Sofia Akrivou, et al.

Neurol Neuroimmunol Neuroinflamm 2015;2;

DOI 10.1212/NXI.0000000000000131

This information is current as of July 2, 2015

Updated Information \&

Services

Supplementary Material

References

Citations

Subspecialty Collections

Permissions \& Licensing

Reprints including high resolution figures, can be found at:

http://nn.neurology.org/content/2/4/e131.full.html

Supplementary material can be found at:

http://nn.neurology.org/content/suppl/2015/08/05/2.4.e131.DC1

This article cites 7 articles, 1 of which you can access for free at: http://nn.neurology.org/content/2/4/e131.full.html\#\#ref-list-1

This article has been cited by 1 HighWire-hosted articles: http://nn.neurology.org/content/2/4/e131.full.html\#\#otherarticles

This article, along with others on similar topics, appears in the following collection(s):

Autoimmune diseases

http://nn.neurology.org//cgi/collection/autoimmune_diseases

Optic neuritis; see Neuro-ophthalmology/Optic Nerve http://nn.neurology.org//cgi/collection/optic_neuritis

Information about reproducing this article in parts (figures,tables) or in its entirety can be found online at:

http://nn.neurology.org/misc/about.xhtml\#permissions

Information about ordering reprints can be found online:

http://nn.neurology.org/misc/addir.xhtml\#reprintsus

Neurol Neuroimmunol Neuroinflamm is an official journal of the American Academy of Neurology.

Published since April 2014, it is an open-access, online-only, continuous publication journal. Copyright $\odot$ 2015 American Academy of Neurology. All rights reserved. Online ISSN: 2332-7812.

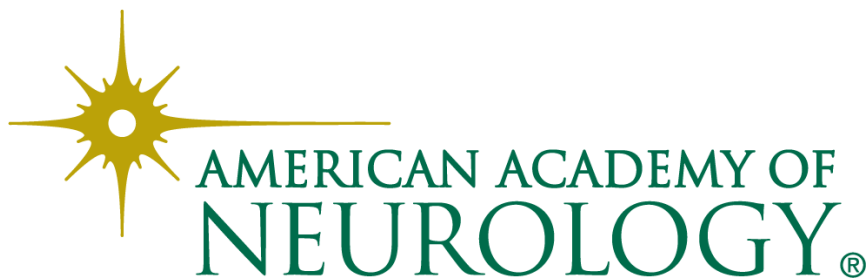

